\title{
MOSQUES OF THE GULF OF EDREMIT
}

\author{
H.S. SAGLAM \\ Polytechnic Milan, Italy.
}

\begin{abstract}
The main settlements at the Gulf of Edremit, Turkey, host a group of historical mosques that were built between the 14th and the 20th centuries. These monuments are in a triangle-shaped geographical area, located within the cities of Edremit, Burhaniye and Ayvalık. Mosques of the Gulf of Edremit coherently represent the early period, the most common simple typology and the last period of the Ottoman mosque architecture. Having clear differences in terms of their period, plan layout and architectural style, local materials and construction techniques are their common points. It is also possible to set connections and link some of these buildings with each other, and also with the surrounding ones.

Keywords: Ayvalık, Burhaniye, Edremit, gulf, mosques, Ottoman architecture.
\end{abstract}

\section{INTRODUCTION}

The reign of the Ottomans led to the construction of numerous mosques within the empire's possessions. These buildings were generally built as a charity work, either by the sultan or a wealthy beneficent. Yet, these monuments were erected in different periods and under different conditions, so they also have different architectural characteristics. The main parts of their plan layout are the same in common mosques, such as the minaret, minbar and the main worship area which is oriented to Mecca through an ornamental mihrab (Eyice [1]).

A typical Ottoman mosque has a single worship space, which is covered by a simple hipped roof or a single dome, and these were usually preferred in relatively smaller scale buildings, starting from very early periods. The hipped roof could have a wooden flat ceiling or a small decorative dome, hidden under the roof space. For covering bigger worship spaces, multiple small domes were transformed into a central dome, supported with four strong pillars and half or quarter domes throughout the 16th century, especially as a result of the architectural innovations contributed by Mimar Sinan. Additions of an external portico for late worshippers and külliye, a complex of buildings adjacent to a mosque for religious functions, were also used widely during this period, all of which characterized the Ottoman classical architecture (Eyice [2]).

The Gulf of Edremit is geographically defined by the Aegean Sea at west, the Mount Ida at north and Madra Mountains from northeast to southwest. The area was under the Seljuk suzerainty from the Byzantines around the 13th and 14th centuries followed by the Ottomans (Öden [3]). There are no monumental mosques in the area by size, but it is possible to find a variety of modest examples from different periods. Stories of these buildings vary between different settlements, but local factors and common implementations act as a bridge between them, and also the ones from other parts of the former empire.

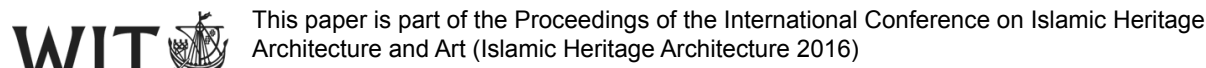

www.witconferences.com
} 


\section{MOSQUES OF THE GULF OF EDREMIT}

The most significant mosques of the Gulf of Edremit are located in the centres of its main settlements: Edremit, Burhaniye and Ayvalık. Few of their villages have historical examples, but only the central ones were studied.

\subsection{Mosques of Edremit}

Kurşunlu Camii (Leaded Mosque) in Edremit could be considered as the most significant example, which was supposed to be built in the late 14th or early 15th century, according to existing historical and architectural proofs (Durmuş [4]). Being undoubtedly the oldest mosque in the area, it represents the early period with its mixed masonry, wide usage of brick material, solid interior volume under a single dome, interior tambour with a sequence of ornamental zigzag triangles and dome transitions with triangular pendentives with elaborate muqarnas. In addition, three single piece columns of its external portico and their composite capitals were originally belonged to an ancient building and reused in the mosque, which were possibly brought from a nearby ruin, that the area is very rich in this case.

The rest of the historical mosques in Edremit (Ağa Camii, Agha Mosque, Kavcı Camii, Tinder Dealer Mosque, Mahkeme Camii, Courthouse Mosque, Pazarlık Camii, Marketplace Mosque and Yakup Ağa Camii, Yakup Agha Mosque) resemble the most common ones with a simpler plan layout and a hipped roof above their main worship spaces. However, Pazarlık Camii is distinguished from the other mosques with its ornamental dome made of timber, hidden under its roof and covering the whole interior space. With this feature and some more architectural details, like its ornamental windows with pointed arches for frames and Moorish arches for openings, which were made of a local dark yellow-light purple stone called 'sarımsak taşı' (garlic stone), mainly from Badavut district of Ayvalık, it shows a remarkable similarity to Vigla/Yalı Camii (Crow's Nest/Shore Mosque) in the island of Lesbos, which after the exchange of the population between Turkey and Greece was converted to a church, dedicated to Saint Nicholas. It is also known that materials and craftsmen were brought from the mainland to the island for major constructions (Töreli [5]), so there is a strong possibility that there is an evidential connection between these two buildings, as the aforementioned features were detected only at these mosques in the area (Fig. 1).

\subsection{Mosques of Burhaniye}

After devastating fires, the biggest mosques of Burhaniye, Koca Camii (Grand Mosque) and Hac1 Ahmet Camii (Hajji Ahmet Mosque), were rebuilt in 1890-1891 and 1911-1912, respectively, designed by the same craftsman: a Greek headworker called Andreas (Aras [7]). His name appears in the corner of Koca Camii, on a marble slab. Centre-domed, barrel-vaulted and cross-shaped plan layouts were in practice at that time, as it is possible to find such examples in nearby cities like Balıkesir (Zağnos Paşa Camii, Zagnos Pasha Mosque, 1461; 1906 with its recent form) or Izmir (Kestanepazarı Camii, Kestanepazarı Mosque, 1667-1668; 1838 with its recent form) (İrkin [8]), but as of the Ottoman classical period, generally half or quarter domes were preferred to provide a transition between bearing walls and the dome. Both mosques were made of local 'sarımsak taşı' where different tones of this stone were preferred in Koca Camii, but Hacı Ahmet Camii has more uniform, dark yellow façades.

With its clear square form, cross-shaped and barrel-vaulted plan layout, small corner domes and lifted small central dome with multiple windows, Hacı Ahmet Camii resembles 

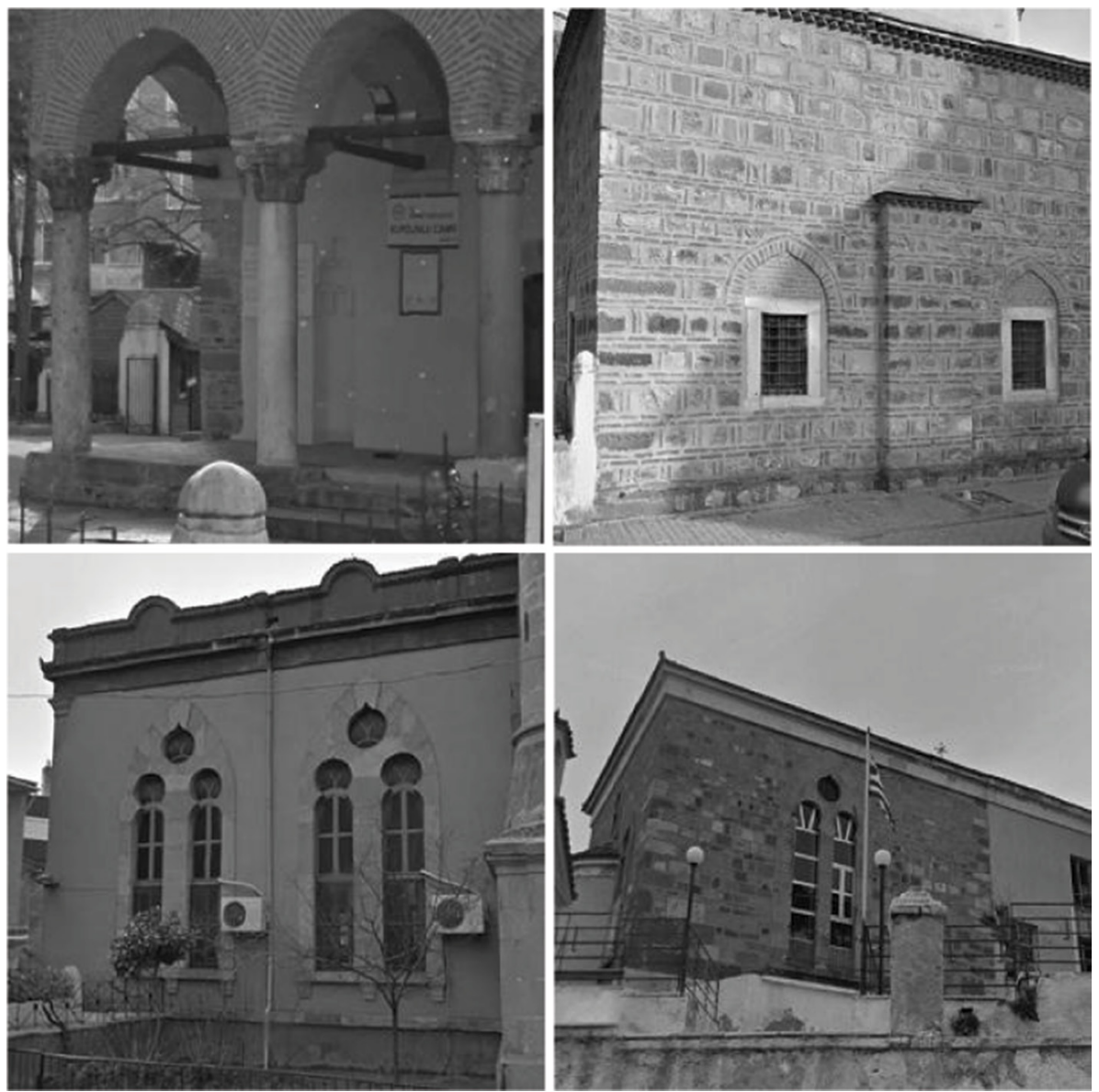

Figure 1: Details from Kurşunlu Camii (above) and Pazarlık Camii and Vigla/Yalı Camii (below) [6].

late Byzantine churches with its unique appearance, although it certainly does not have such a history. Therefore, it could be that the craftsman Andreas might have had other inspirations during the design process. In addition, four bearing columns of its main dome have ancient origins, as it is in Kurşunlu Camii of Edremit, and these Doric pieces were brought from the ruins of Pergamon ancient city (Aras [9]). The usage of ancient materials in new constructions often linked with the early period, as the financial power and technological advances of the empire to provide finely processed construction materials were naturally less, but it is possible to find reused material also in late period Hacı Ahmet Camii. The main distinction between these two usages is their form: Kurşunlu Camii has different and rough pieces, but the ones at Hac1 Ahmet Camii are more uniform and finished.

The other two historical mosques of the town (Hasan Ağa Camii, Hasan Agha Mosque and Hanay Camii, Two-storied Mosque, both built in 1758-1759) have a simpler plan layout, but only Hasan Ağa Camii has a very small, ornamental dome, hidden under its wooden roof. This dome was previously standing alone but four wooden pillars were added afterwards 

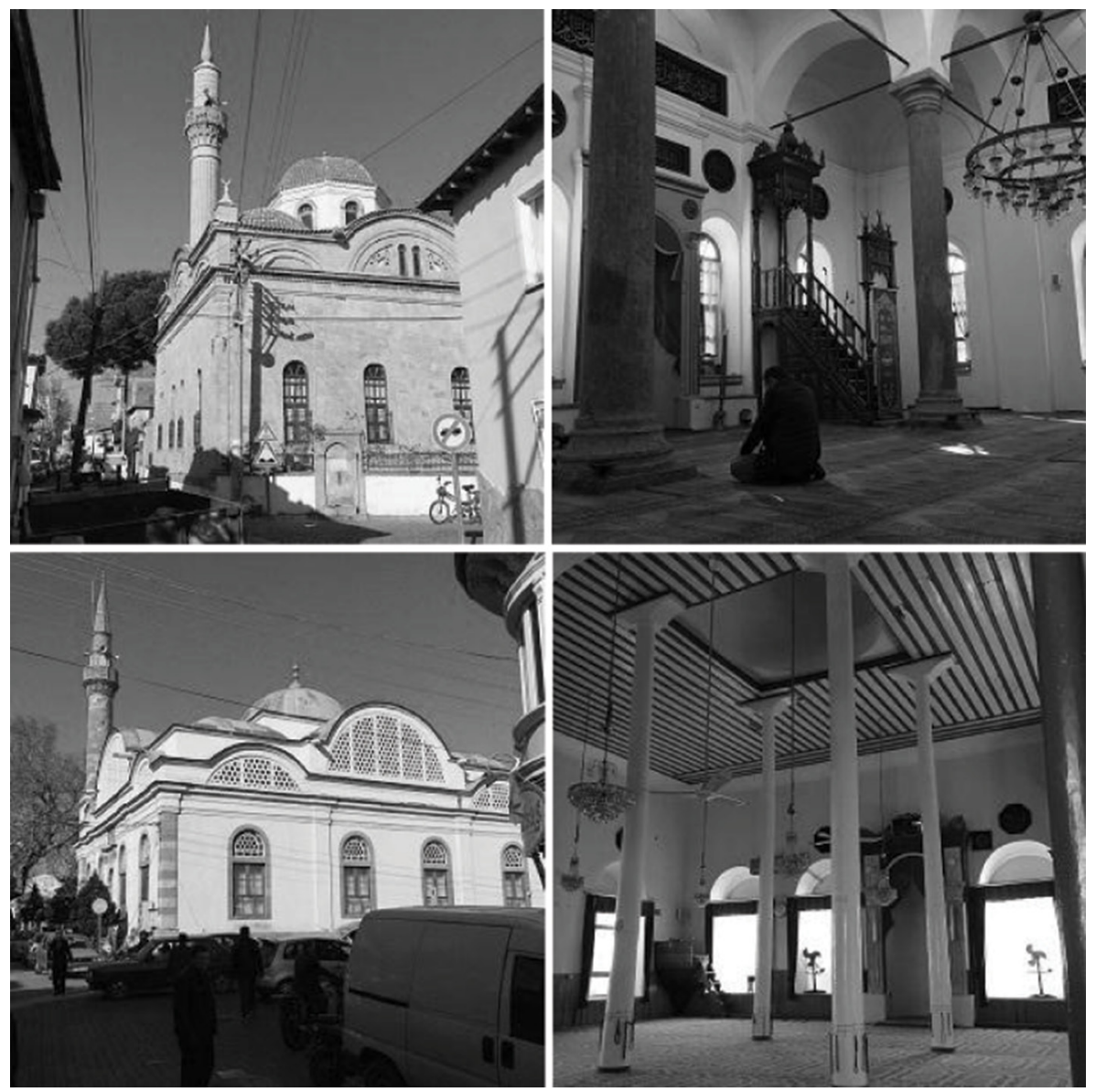

Figure 2: Views and details from Hacı Ahmet Camii (above) and Koca Camii and Hasan A ğa Camii (below).

(possibly in 1877-1878) to give an extra support. In addition, founders of Burhaniye Hanay Camii, Hacı Ali Ağa and Edremit Ağa Camii, Mehmet Emin Ağa were brothers. The latter was the commander of these towns in the mid-18th century and built another mosque in Burhaniye in 1742, which still bears his name, but this mosque was completely demolished and rebuilt in 1961 (Fig. 2).

\subsection{Mosques of Ayvalık}

The majority of Ayvalık's population before the population exchange consisted of local Greeks. Therefore, the city had 21 Greek Orthodox churches but only 2 mosques in its centre and the island district of Cunda. Both these mosques were built in the late 19th century.

Ayvalık mosques were built as a result of Sultan Abdul Hamid II's personal initiative in their construction, so both of them were called Hamidiye Camii (Hamidiye Mosque). The one at Ayvalık city is located in the northern outskirts of the historical centre and was built around 
1889 (Özel [10]). Hamidiye Camii of Cunda was built in 1898 and is located in the island of Cunda at west. The mosques were finely built with local 'sarımsak taşı', like the majority of the buildings in Ayvalık, as this construction material used to be extracted from the city. Both of them have a neoclassical style and an external portico with a triangular pediment above four bearing columns. Neoclassicism was the dominant style among the shrines of the town that four of seven former Greek Orthodox churches in Ayvalık were also built in this style: Hagios Georgios (today Çınarlı Camii/Plane Tree Mosque), Hagios Ioannes (today Saatli Camii/Clock Mosque), Ayazma (Holy Spring) and Portaitissa. Only Ayazma Church, which was built in 1890, had a neoclassical portico similar to that of the mosques. The windows and the main gate of Ayvalık Hamidiye Camii have sharp pointed arches but Hamidiye Camii of Cunda has these arches only on its portico openings. These sharp pointed arches are very
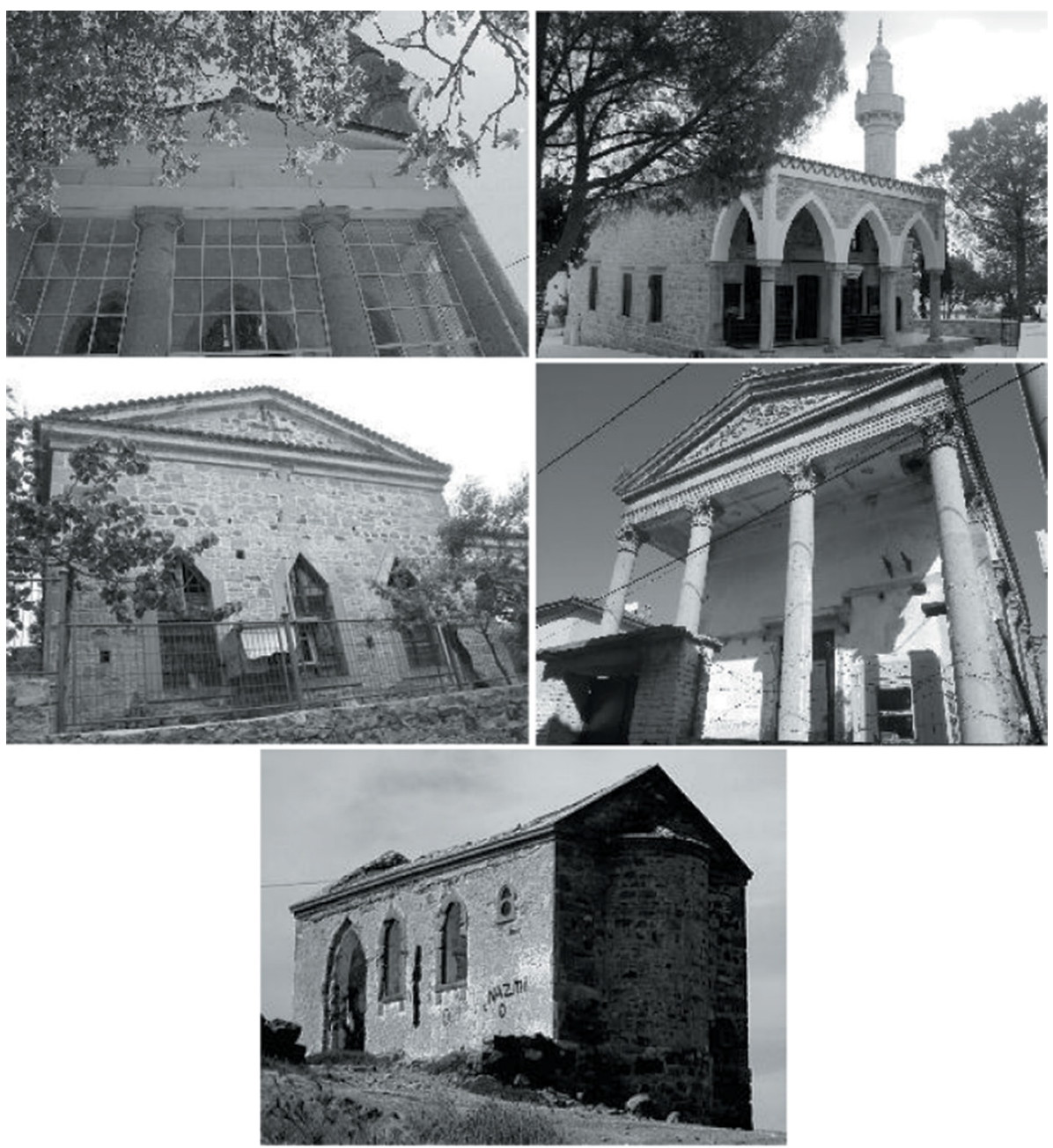

Figure 3: Details from Ayvalık Hamidiye Camii [11] and Cunda Hamidiye Camii [12] (above), Portaitissa [13] and Ayazma [14] churches (centre) and Hagios Ioannes Chapel [15] (below). 
similar to the ones at the former Portaitissa Church and Hagios Ioannes Chapel in Cunda Island, which implies that these churches were built in the late 19th century as well.

By form, Ayvalık Hamidiye Camii has a dome and Cunda Hamidiye Camii has a hipped roof with a flat ceiling on their single worship spaces. In this case, it can be said that the mosques of Ayvalık follow the traditional Ottoman architecture by their plan layouts, despite having a slightly modern stylistic approach at that time (Fig. 3).

\section{CONCLUSION}

Similarities and connections between buildings of the same type located in the same area are more than natural. However, these links need to be defined, for a better understanding of these monuments and the area where they are located. It is seen that mosques of the Gulf of Edremit follow the general traditions of Ottoman mosque architecture in their plan layout, like the domed early period, cross-shaped classical architecture and roofed simple type, but additionally they also have some particular individual characteristics. For instance, Kurşunlu Camii in Edremit and Hac1 Ahmet Camii in Burhaniye have significant ancient construction material reusage, but the quality of the adaptation is not the same for these ancient materials, which is due to the difference in these mosques' construction periods. Hac1 Ahmet Camii could also be described as a variation of cross-shaped and centre-domed plan type, as it can be easily exemplified with nearby Koca Camii. Yet, it has a unique appearance because of its designer. The mosques of Burhaniye are also the only ones without an external portico in the area. There are structural and architectural similarities between Pazarlık Camii in Edremit and Vigla/Yalı Camii in Lesbos, which raises the possibility of same designers behind their construction. Similarities between Ayvalık mosques and former Greek Orthodox churches by material, architectural style and some other details are consequential too, which makes them a part of the town in a coherent way. Mosques with a hipped roof and a flat ceiling over a single worship place, which is the simplest type, could be found in all three cities.

Coming from the same traditional and local origins, mosques of the Gulf of Edremit differ in significant architectural points and although levels of this differentiation change from one settlement to another, there are many common points.

\section{REFERENCES}

[1] Eyice, S., Cami, TDV İslam Ansiklopedisi: Istanbul, Vol. 7, pp. 56-58, 1988.

[2] Eyice, S., Cami, TDV İslam Ansiklopedisi: Istanbul, Vol. 7, pp. 70-85, 1988.

[3] Öden, Z.G., Karesioğulları, TDV İslam Ansiklopedisi: Istanbul, Vol. 24, p. 488, 1988.

[4] Durmuş, S., Edremit ve Köylerindeki Türk Eserleri, Ege University Unpublished Master's Thesis: Izmir, pp. 40-43, 2010.

[5] Töreli, T., Midilli ve Kıblesi Mekke'ye Bakan Bir Kilise Hakkında Bazı Tarihi Tespitler. Tarih Okulu Dergisi, Year: 8, XXII, p. 468, 2015.

[6] Retrieved from Google Street View, available at https://www.google.com/maps (accessed 10 November 2015).

[7] Aras, Y., Körfeze İsmini Veren Şehir Adramytteion-Kemer-Burhaniye'de CamilerVakıflar-Şeyh Muhyiddin-i Rumi, Burhaniye Belediyesi: Burhaniye, pp. 33-39, 2006.

[8] İrkin, Ö.M., Burhaniye'deki Türk Devri Eserleri, Dokuz Eylül University Unpublished Master's Thesis: Izmir, p. 34, 2006.

[9] Aras, Y., Körfeze İsmini Veren Şehir Adramytteion-Kemer-Burhaniye'de CamilerVakıflar-Şeyh Muhyiddin-i Rumi, Burhaniye Belediyesi: Burhaniye, p. 39, 2006. 
[10] Özel, M.K., Kent Strüktürü ile Tapınma Yapıları Arasındaki İlişki Bağlamında Ayvalık Hamidiye Camisi, Tasarım + Kuram: Istanbul, Vol. 7, Issue: 11-12, p. 34, 2011.

[11] Ayvalık Turizm - Ayvalık Hakkında Her Şey, available at http://ayvalikturizm.blogspot. com/2011/09/ayvalk-hamidiye-camii.html (accessed 10 November 2015).

[12] Gezgin Rehberler, available at http://www.gezginrehberler.com/balikesir/hamidiyecamii-cunda-balikesir (accessed 11 November 2015).

[13] Ayvalikda - Uysal, O. S., available at http://www.ayvalikda.com/portaitissa-kilisesi. html (accessed 12 November 2015)

[14] Öz Ortodoksluk Doktrinleri ve Emanetleri, available at http://oodegr.co/tourkika/ieroi_ xwroi/ayiasma_fanerwmenis_ayvali.htm (accessed 12 November 2015).

[15] Mapio.net, available at http://www.mapio.cz/s/65124207 (accessed 12 November 2015). 